\title{
Nutrient distribution in a shallow subtropical lagoon, south Brazil, subjected to seasonal hypoxic and anoxic events
}

\author{
Georgia de Barros ${ }^{1 *}$, Alessandra Larissa D'Oliveira Fonseca ${ }^{2}$, Alex Cabral dos Santos ${ }^{1}$, \\ Maria Luiza Schmitz Fontes ${ }^{3}$, Alejandro Rodolfo Donnangelo Varela ${ }^{1}$, Davide Franco ${ }^{4}$
}

\author{
${ }^{1}$ Universidade Federal de Santa Catarina. \\ (Campus Universitário Trindade, 88040900 - Florianópolis - Santa Catarina - Brasil) \\ ${ }^{2}$ Louisiana State University. \\ (1002-Y Energy, Coast \& Environment Building · Baton Rouge, LA 70803) \\ ${ }^{3}$ University of Technology Sydney, Austrália. \\ (City Campus, 15 Broadway, Ultimo NSW 2007 \\ ${ }^{4}$ Università Degli Studi Di Venezia, Itália. \\ (Dorsoduro, 3246, 30123 Venezia, Itália)
}

*Corresponding author: georgiadebarros78@gmail.com

\section{Abstract}

The Conceição Lagoon, located in south Brazil, is a semi-enclosed coastal ecosystem that has seasonal hypoxic and anoxic conditions in its vertically stratified central region, characterized as a site of retention and mineralization of organic matter. This study investigates water column dynamics in the central region of the Conceição Lagoon (CCL) and its relation to physical and chemical variables, in order to understand the hypoxic and anoxic events. Surface, halocline and bottom waters were evaluated at three sampling sites along the CCL. The samples were collected in triplicate during the summer, fall and winter of 2014. Hypoxic and/or anoxic events occurred in the summer $(1 / 21)$ at the halocline $(3 \mathrm{~m})$ and bottom $(4 \mathrm{~m})$ waters, and in the fall $(2 / 5)$ in the bottom water $(4.5 \mathrm{~m})$. Positive values of apparent oxygen utilization showed mineralization processes in the halocline and bottom waters. The lowest vertical stratification index was recorded in August (southern winter), which was associated with wind speed $\left(14.7 \mathrm{~m} . \mathrm{s}^{-1}\right)$ and direction (southern quadrant). Nutrient concentrations were higher in winter, related to increasing of water mixing. This was the first study to evaluate the dynamics of hypoxic and anoxic events in the CCL and how nutrients respond to the physical structure of the water column.

Descriptors: Eutrophication, Stratification, Dead zones, Mineralization.

\section{Resumo}

A Lagoa da Conceição, localizada no sul do Brasil, é um ecossistema costeiro semifechado que apresenta eventos sazonais de hipoxia e anoxia na região central, caracterizada pela coluna de água estratificada e sítio de retenção e mineralização da matéria orgânica. Este estudo investigou a dinâmica da coluna de água da região central da Lagoa da Conceição (CLC) em relação às variáveis físicas, químicas e biológicas, com o objetivo de entender os eventos de hipoxia e anoxia. As águas de superfície, haloclina e fundo foram avaliadas em três pontos amostrais. As amostras foram coletadas em triplicata durante o verão, outono e inverno de 2014. Eventos de hipoxia e/ou anoxia ocorreram somente nas águas de haloclina $(3 \mathrm{~m})$ e fundo $(4 \mathrm{~m})$ do verão. Valores próximos a $100 \%$ de uso aparente de oxigênio indicaram processos de mineralização nas águas de fundo. O menor valor do índice de estratificação vertical foi observado em agosto (inverno austral), que foi correlacionado com a velocidade (14,7 m.s. $\left.{ }^{-1}\right)$ e direção (quadrante sul) do vento. As concentrações de nutrientes foram maiores no inverno, devido ao aumento dos processos de mistura e remineralização da matéria orgânica. Este foi o primeiro estudo a avaliar a dinâmica dos eventos de hipoxia/anoxia na CLC em relação à distribuição dos nutrientes e estrutura física da coluna de água.

Descritores: Eutrofização, Estratificação, Zonas mortas, Mineralização. 


\section{INTRODUCTION}

Coastal lagoons are dynamic environments with limited water exchange, which strongly affects the temporal variation of physical, chemical and biological properties of water column (NOGUEIRA et al., 1997; NEWTON et al., 2003). The allochthonous matter introduced into these systems, either naturally or by anthropogenic inputs, is efficiently retained due to the high water residence time, reduction of energy sources (i.e., tides, currents and waves) and the strong coupling in the water/sediment interface, and this retention is intensified by eutrophication processes (CLOERN, 2001; GREY et al., 2002; KENNISH; PAERL, 2010).

Hypoxic and anoxic events are frequent in coastal waters worldwide, where its occurrence, duration and magnitude are increasing by human activities (i.e., domestic sewage and agriculture) (DIAZ; ROSENBERG, 2008). Hypoxic conditions occur when dissolved oxygen (DO) concentrations are below $2.0 \mathrm{mg} . \mathrm{L}^{-1}$ (RABALAIS, 2004). Low levels of DO can alter biological behavior, reduce growth and increase mortality in numerous marine species, and it also may disrupt biogeochemical processes (e.g. nutrient cycling) (DÍAZ, 2001; RABALAIS; TURNER, 2001; RABALAIS, 2004; STECKBAUER et al., 2011; LIU et al., 2012). The main drivers for boosting these hypoxic events are water column stratification and high organic matter load (RABALAIS et al., 1998; DIAZ et al., 2001; STRAMMA et al., 2008).

In order to predict the occurrence of hypoxic events, it is important to evaluate the balance between evaporation/ precipitation, wind direction and intensity. These factors influence water column stratification, turbidity, residence time, and nutrient dilution processes (RABALAIS et al., 1998; CLOERN, 2001; MCGLATHERY et al., 2001; KENNISH; PAERL, 2010). Many studies have reported the effect of increasing atmospheric temperature on shifts in wind pattern, resulting on stronger water column stratification and, thus, occurrence and persistence of anoxic and hypoxic zones around the world (ZANCHETTIN et al., 2007; LLORET et al., 2008; RABALAIS et al., 2010).

DÍAZ; ROSENBERG (2008) reported 415 coastal systems in eutrophication process, where $41 \%$ had hypoxic zones (SELMAN et al., 2008). This study also presented 6 Brazilian coastal ecosystems with eutrophic and hypoxic conditions, including the Conceição Lagoon (CL). Seasonal events of hypoxia and anoxia have been reported in this system, particularly in the bottom waters of the central region (CCL), which is connected to the adjacent ocean by a narrow shallow channel (KNOPPERS et al., 1984; ODEBRECHT; CARUSO Jr., 1987; SIERRA DE LEDO; SORIANO-SIERRA, 1994; FONSECA; BRAGA, 2006; FONTES et al., 2006; FONTES; ABREU, 2009; FONTES et al., 2011).

Constant anoxic and hypoxic events began to be observed in the CL after the permanent opening of the Barra Channel in 1982 (ODEBRECHT; CARUSO Jr., 1987). These events are often reported in fall, when oxygen biological consumption is stimulated by higher production of autochthonous and allochthonous organic matter (OM) produced in the summer (ODEBRECHT; CARUSO Jr., 1987; FONTES et al., 2011). However, oxygen supersaturation (oxygenic photosynthesis) in the bottom water of the CCL has been reported in summer due to high nutrient availability and sunlight incidence (ODEBRECHT; CARUSO Jr., 1987; FONTES; ABREU, 2009). The seasonal nutrient variability within the CL can be driven by primary productivity assimilation and remineralization processes, which the first is prevalent in spring/summer and the last in fall/winter (ODEBRECHT; CARUSO Jr., 1987; FONSECA; BRAGA, 2006; FONTES et al., 2006; FONTES; ABREU, 2009; FONTES et al., 2011; 2012).

The most frequent winds in the CL are the northern winds, but the strongest are the southern winds, prevalent in winter, associated with cold fronts (ODEBRECHT; CARUSO Jr., 1987). The effects of meteorological tides prevail over astronomical tides, but usually $98 \%$ of total tidal energy is dissipated along the channel before it gets inside the CL (GODOY, 2008). Monthly precipitation ranges between 74.1 and $172.4 \mathrm{~mm}$, with more frequent rainfall in summer and spring (CRUZ, 1998). The main freshwater sources to the $C L$ are precipitation, streams and groundwater (SIERRA DE LEDO; SORIANO-SERRA, 1994). Its principal tributary is the João Gualberto Soares River, which flows into the northern sector of the lagoon.

Previous studies have characterized the lagoon in 3 regions (south, central and north) according to physical and chemical characteristics of the water (ASSUMPÇÃO et al., 1981; KNOPPERS et al., 1984; ODEBRECHT; CARUSO Jr., 1987; SOUZA-SIERRA et al., 1987; MUEHE; CARUSO Jr., 1989; FONSECA et al., 2002). A stratified water column has been observed in CCL, with meso to polyhaline characteristics and frequent hipoxic/ anoxic bottom waters due to the high water residence time and accumulation of organic matter (KNOPPERS et 
al., 1984; SOUZA-SIERRA et al., 1987; ODEBRECHT; CARUSO Jr., 1987; FONSECA et al., 2002), and high stratification index (FONTES; ABREU, 2009). Considering the dynamics of hypoxic-anoxic events in the CCL, the overall objective of our study was to evaluate how nutrients and physicochemical characteristics of the water column can be related to eutrophication process, in order to better understand the causes of seasonal hypoxic and anoxic events.

\section{MATERIALS AND METHODS}

\section{STUDY AREA}

Conceição Lagoon (CL) is a semi-enclosed coastal ecosystem that is connected to the open ocean by a $2 \mathrm{~km}$ narrow channel (Figure 1). It encompasses a watershed area of $80 \mathrm{~km}^{2}$ and a total lagoon water body of $20 \mathrm{~km}^{2}$. The CL has $13.5 \mathrm{~km}$ in length with a width between 0.5 and $2.5 \mathrm{Km}$, with depths ranging between 1.7 and 8.7 meters (KNOPPERS et al., 1984; MUEHE; CARUSO Jr., 1989) (Figure 1).

\section{DATA COLLECTION}

CCL waters were sampled in triplicate during summer $(1 / 21 / 2014,2 / 5 / 2014$ and $2 / 25 / 2014)$, fall $(5 / 8 / 2014$, $5 / 15 / 2014$ and 5/27/2014) and winter (7/10/2014, $7 / 30 / 2014$ and 8/14/2014). Sampling sites are shown in Figure 1. Temperature $\left({ }^{\circ} \mathrm{C}\right)$, salinity, dissolved oxygen and saturation (mg. $\mathrm{L}^{-1}$ and \%), and photosynthetically active radiation (PAR $\mu$ mol.quanta. $\mathrm{m}^{-2} . \mathrm{s}^{-1}$ ) were measured every $0.5 \mathrm{~m}$ with a thermosalinometer (model EC 300 YSI), an oximeter (YSI model 55) and a radiometer (Biosciences LI Cor model 2501) from surface to $0.5 \mathrm{~m}$ above the bottom. Subsurface $(0.5 \mathrm{~m})$, halocline (defined by the salinity data during the fieldwork) and bottom ( 0.5 $\mathrm{m}$ above the bottom) waters were sampled using a Van Dorn bottle. Water samples were then transferred to 500 $\mathrm{mL}$ polyethylene bottles (pre-washed with $10 \% \mathrm{HCl}$ ) and stored at $4{ }^{\circ} \mathrm{C}$ (protected from light) until filtration.

In the laboratory, samples were filtered through a 0.7 $\mu \mathrm{m} \mathrm{GF/F} \mathrm{(Macherey-Nagel),} \mathrm{where} \mathrm{filters} \mathrm{and} \mathrm{filtrates}$ were frozen at $-20{ }^{\circ} \mathrm{C}$ until analysis. Nitrate+nitrite

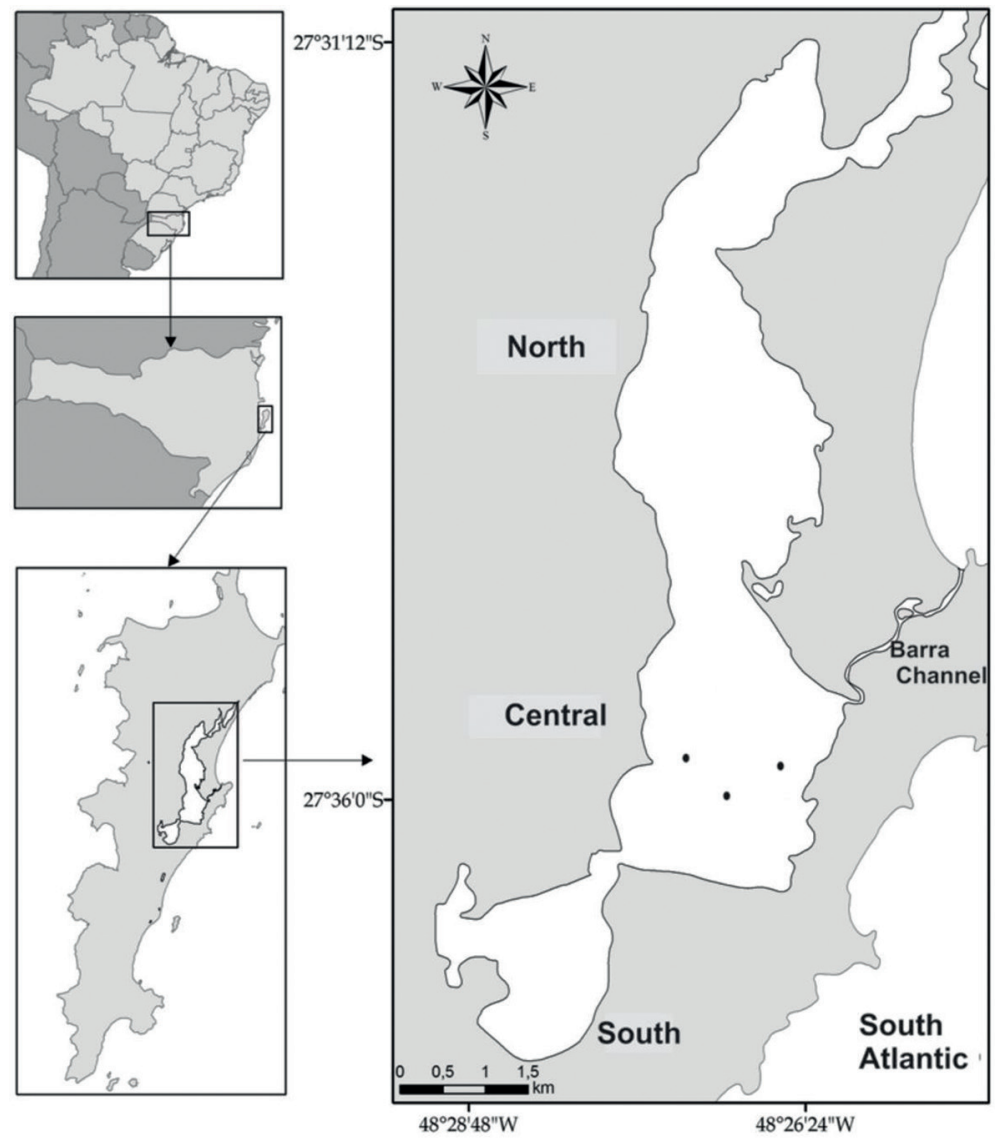

Figure 1. Sampling stations in the central region of Conceição Lagoon (SC), Brazil. Adapted from Fontes et al., 2009. 
$\left(\mathrm{NO}_{3+2}^{-}\right)$, ammonium $\left(\mathrm{NH}_{4}^{+}\right)$, phosphate $\left(\mathrm{PO}_{4}{ }^{3-}\right)$ and silicate $\left(\mathrm{SiO}_{2}\right)$ were determined by colorimetric method (GRASSHOFF et al.,1983) using a spectrophotometer (Hitachi model U-2900 with sipper).

Photosynthetic pigments (chlorophyll-a (Chl-a) and pheophytin-a (Feo-a)) retained in the filters were extracted with $90 \%$ acetone (v/v) at $4{ }^{\circ} \mathrm{C}$ in the dark over a period of 24 hours. Pigment concentrations were determined by the Lorenzen method, using a spectrophotometer (Bioespectro model SP-120) with a $5 \mathrm{~cm}$ optical path cuvette, following the recommendations of STRICKLAND; PARSONS (1972).

The apparent oxygen utilization (AOU) in percentage saturation (\%) was calculated according to BENSON; KRAUSE (1984). The water column stratification index was calculated as the difference between the surface water density and the density at the bottom, defined from in situ salinity and temperature measurements.

Time series of wind speed and direction were extracted from ERA-Interim re-analysis (http://www.ecmwf. int/en/research/climate-reanalysis/browse-reanalysisdatasets) at the closest grid point to the CCL, five days before each sampling. Wind roses containing speed and direction frequencies were plotted for each sampling period using MATLAB R2013a (license number 832064). Daily precipitation $(\mathrm{mm})$ data were acquired from the EPAGRI/SC weather station, located near the CL. We only considered data from five days preceding sampling days, since they are critical for the stability of the water column.

\section{DATA ANALYSIS}

Multivariate permutational analysis of variance (PERMANOVA) was used to assess spatial (in depth) and temporal (between sampling periods) differences in DO, PAR, salinity, temperature, nutrient concentration and phytoplankton pigment concentrations. Multidimensional scaling analysis (MDS) was concomitantly performed based on the Euclidean distances to generate a graphic representation of the similarity (or distance) matrix. Stress $=0.1$ was considered satisfactory for goodnessof-fit (CLARKE; WARNICK, 1994). A simple Pearson correlation was carried out using $\mathrm{R}$ Console Program (3.0.3) with a p-value of 0.05 . The PERMANOVA and MDS were performed in PRIMER program (Plymouth Routine in Multivariate Ecological Research-Plymouth University).

\section{RESULTS}

\section{Meteorological Data}

The wind speed ranged from 0.3 to $8.2 \mathrm{~m} \cdot \mathrm{s}^{-1}$ during summer and the predominantly wind direction was from the north quadrant (Figure 2), as expected. Stronger winds were observed in winter (1.0 to $\left.14.7 \mathrm{~m} . \mathrm{s}^{-1}\right)$ and fall $(0.7$ to $12.5 \mathrm{~m} . \mathrm{s}^{-1}$ ) (Figure 2). The predominant winds were the southern winds, followed by northern winds in the fall (Figure 2).

In summer, a maximum of $75.3 \mathrm{~mm}$ of precipitation was observed, which occurred on one day prior to the last sampling of this season (Figure 3). Precipitation values were lower in winter, with intermediate values in fall (Figure 3).

\section{PHYSICAL-CHEMICAL VARIABLES}

Water column stratification in the CCL was determined by salinity, which ranged from 24.4 to 32.2 (Table 1). The vertical stratification index ranged from 1.4 $\mathrm{Kg} . \mathrm{m}^{-3}$ (winter) to $6.3 \mathrm{Kg} \cdot \mathrm{m}^{-3}$ (summer), and an inverse correlation $(r=-0.7, p>0.001, n=27)$ between stratification index and wind speed was observed (Figure 4).

The incident PAR on the surface water in summer was about twice the incident PAR in the fall $(1347 \mathrm{mmol}$. quanta. $\mathrm{m}^{-2} \cdot \mathrm{s}^{-1}$ and $681 \mathrm{mmol}$.quanta. $\mathrm{m}^{-2} \cdot \mathrm{s}^{-1}$, respectively) and 13 times higher than in winter (104 mmol.quanta.m$\left.{ }^{2} \cdot \mathrm{s}^{-1}\right)$ (Figure 5). The euphotic zone reached the bottom of the CCL in most of the sampling days, except in February $5^{\text {th }}$ and $25^{\text {th }}$ (Table 1).

Hypoxic and anoxic bottom waters were observed only in summer (Figure 5), while higher averages of bottom DO concentrations were detected in winter (Figure 5). There was a significant inverse correlation between bottom water DO and water column stratification index ( $\mathrm{r}$ $=-0.65, \mathrm{p}<0.05, \mathrm{n}=27)$ throughout the study. AOU values were significantly higher in the bottom waters. AOU in the surface waters ranged between $-32.2 \%$ (supersaturation) and $18.4 \%$ (unsaturation), while halocline and bottom waters maintained unsaturated, ranging from $9.4 \%$ to $90.9 \%$ and from $25.2 \%$ to $99.7 \%$, respectively (Figure 5).

\section{DISSOLVED INORGANIC NUTRIENTS AND} PHOTOSYNTHETIC PIGMENTS

The mean concentrations of dissolved inorganic nitrogen (DIN, $\left(\mathrm{NO}_{3+2}{ }^{-}+\mathrm{NH}_{4}^{+}\right)$) and phosphate (DIP 
SUMMER
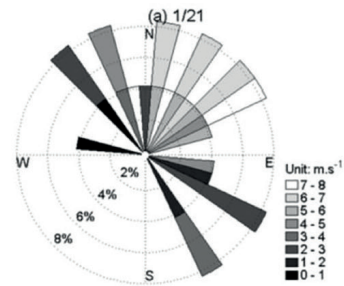

FALL
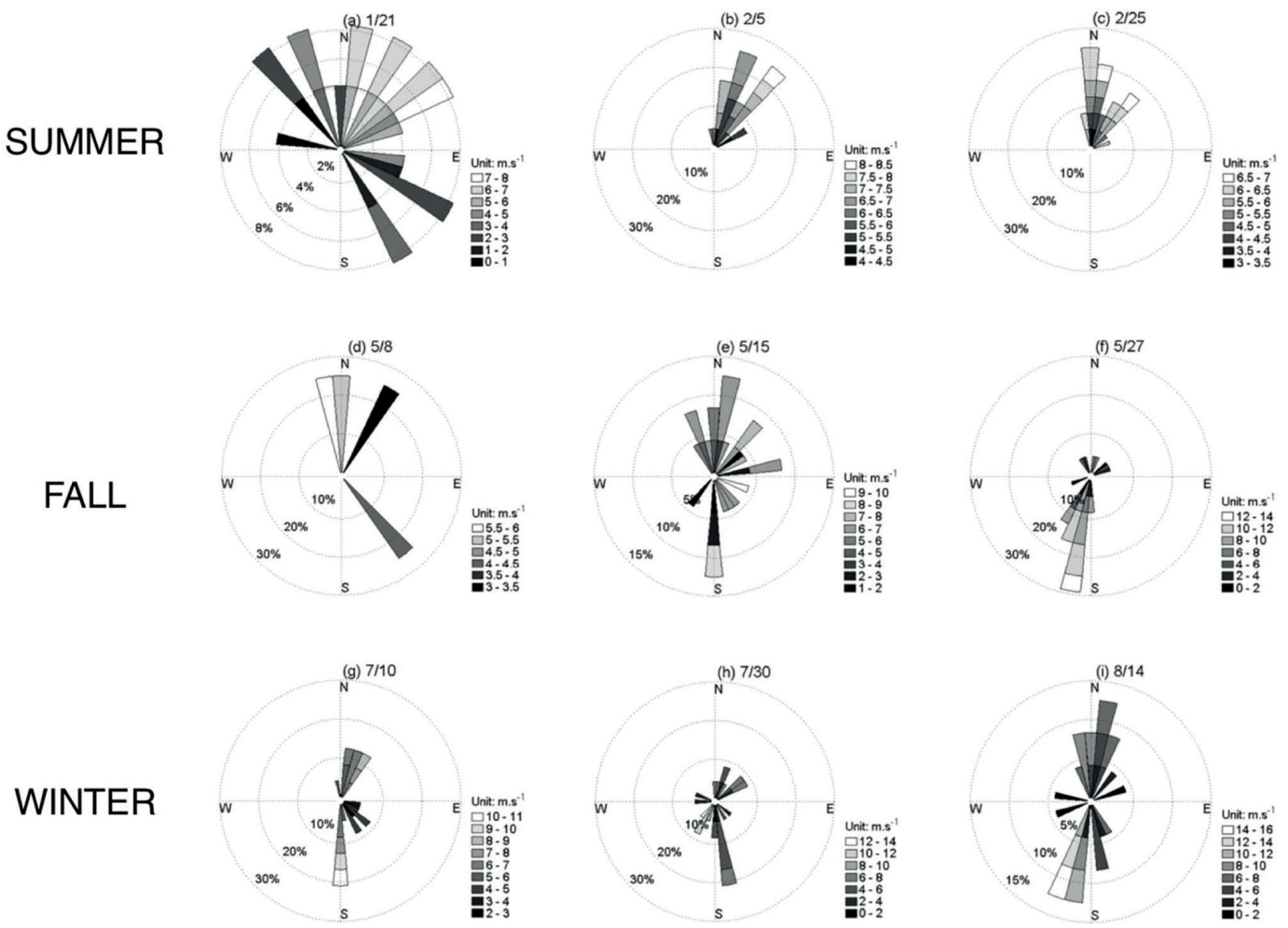
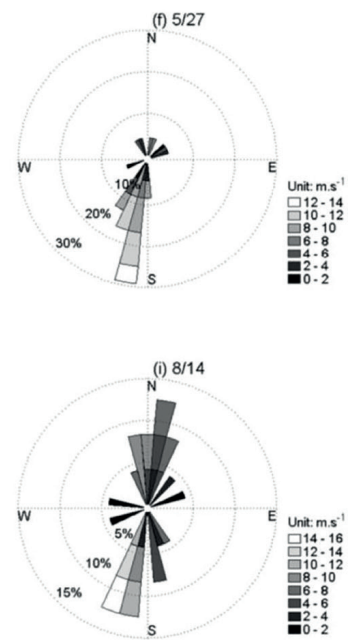

Figure 2. Wind roses showing the speed and predominant wind direction accumulated five days before each sampling expedition and during the day of sampling in summer (1/21(a), 2/5(b) and 2/25(c)), fall (5/8(d), 5/15(e) and 5/27(f)) and winter (7/10(g), 7/30(h) and 8/14(i)). Source: ERA-Interim re-analysis.

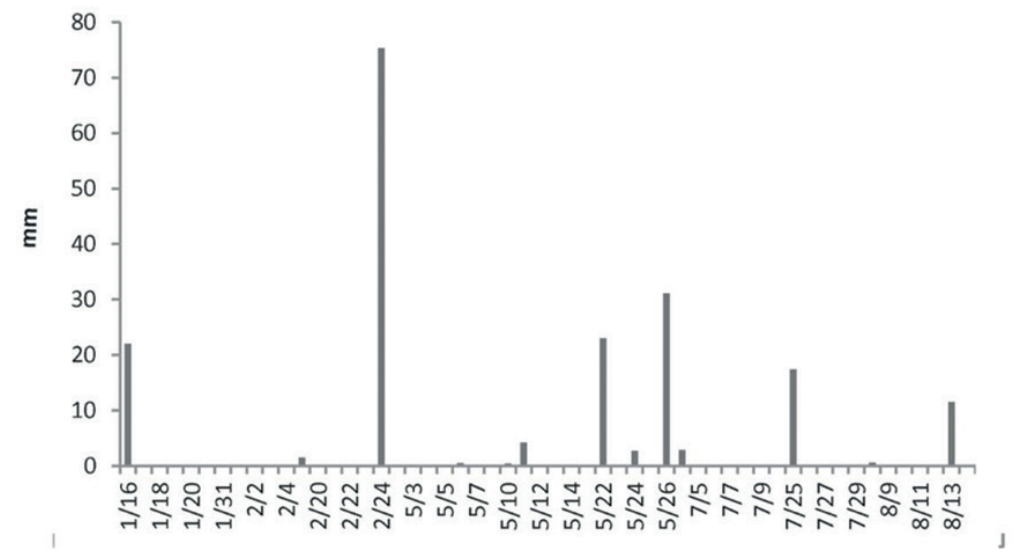

Figure 3. Daily rainfall average $(\mathrm{mm})$ during previous five days of sampling and during the day of sampling in summer $(1 / 2,2 / 5$ and $2 / 25)$ autumn $(5 / 8,5 / 15$ and $5 / 27)$ and winter $(7 / 10,7 / 30$ and 8/14) of 2014. Source: EPAGRI/SC.

$\left(\mathrm{PO}_{4}^{3-}\right)$ ) in summer were $1.2 \pm 0.9 \mu \mathrm{M}$ and $0.1 \pm 0.1 \mu \mathrm{M}$, in fall, $2.9 \pm 2.5 \mu \mathrm{M}$ and $0.1 \pm 0.1 \mu \mathrm{M}$, and in winter $6.6 \pm 4.5$ $\mu \mathrm{M}$ and $0.2 \pm 0.1 \mu \mathrm{M}$, respectively (Figure 6). Ammonium represented $68 \%$ of total DIN in summer, $69 \%$ in fall, and $97 \%$ in winter. Average NP ratio was $21.8 \pm 10.4$ in summer, $42.7 \pm 39.3$ in fall, $41.7 \pm 32.2$ in winter (Table 2).
Ammonium concentrations increased from summer to winter and the highest values were observed in bottom waters (2.7 $\mu \mathrm{M}$ ) (Figure 7). Silicate was usually low in this study, ranging from $0.1 \mu \mathrm{M}$ (surface water in fall) to $20.6 \mu \mathrm{M}$ (bottom water in winter), when compared to previous studies (FONSECA; BRAGA, 2006; FONTES et al., 2009) (Figure 7). 
Table 1. Mean values $( \pm \mathrm{SD})$ of temperature $\left({ }^{\circ} \mathrm{C}\right)$, salinity and PAR $(\%)$ at the surface, halocline and bottom waters of the CCL in the summer $(1 / 21,2 / 5$ and $2 / 25)$, fall $(5 / 8,5 / 15$ and 5/27) and winter $(7 / 10,7 / 30$ and 8/14) of 2014.

\begin{tabular}{|c|c|c|c|c|}
\hline Date & Depth (m) & Temperature & Salinity & PAR \\
\hline \multirow{3}{*}{$1 / 21$} & 0.5 & $29.1 \pm 0.5$ & $24.5 \pm 0.2$ & $19.1 \pm 7.1$ \\
\hline & 3 & $27.4 \pm 0.1$ & $30.1 \pm 0.3$ & $2.4 \pm 0.2$ \\
\hline & 4 & $26.3 \pm 0.4$ & $30.7 \pm 0.2$ & $1.3 \pm 0.5$ \\
\hline \multirow{3}{*}{$2 / 5$} & 0.5 & $25.1 \pm 0.2$ & $25.8 \pm 0.2$ & $11.5 \pm 4.7$ \\
\hline & 3.5 & $23.7 \pm 0.2$ & $28.2 \pm 0.2$ & $1.1 \pm 0.4$ \\
\hline & 4.5 & $20.2 \pm 0.2$ & $31.7 \pm 0.2$ & $0.2 \pm 0.1$ \\
\hline \multirow{3}{*}{$2 / 25$} & 0.5 & $21.3 \pm 0.1$ & $26.2 \pm 0.1$ & $29 \pm 18$ \\
\hline & 3.5 & $20.4 \pm 1.2$ & $28.2 \pm 0.5$ & $2.5 \pm 1.3$ \\
\hline & 4 & $18.2 \pm 1.6$ & $32.1 \pm 0.2$ & $0.7 \pm 0.4$ \\
\hline \multirow{3}{*}{$5 / 8$} & 0.5 & $23.3 \pm 0.2$ & $27.1 \pm 0.2$ & $18.2 \pm 0.2$ \\
\hline & 3 & $23.3 \pm 0.2$ & $31.1 \pm 0.2$ & $5.8 \pm 0.2$ \\
\hline & 4 & $23.4 \pm 0.3$ & $32.2 \pm 0.2$ & $1.2 \pm 0.1$ \\
\hline \multirow{3}{*}{$5 / 15$} & 0.5 & $21.7 \pm 0.3$ & $27.2 \pm 0.1$ & $28.4 \pm 9.2$ \\
\hline & 2.5 & $22.1 \pm 0.1$ & $29.2 \pm 0.2$ & $10.6 \pm 2.3$ \\
\hline & 4 & $23.1 \pm 0.2$ & $32.1 \pm 0.1$ & $3.2 \pm 1.1$ \\
\hline \multirow{3}{*}{$5 / 27$} & 0.5 & $18.8 \pm 0.1$ & $28.2 \pm 0.2$ & $16.5 \pm 1.1$ \\
\hline & 4 & $20.2 \pm 0.1$ & $30.1 \pm 0.1$ & $5.6 \pm 0.8$ \\
\hline & 5 & $21.5 \pm 0.2$ & $32.2 \pm 0.2$ & $2.6 \pm 2.5$ \\
\hline \multirow{3}{*}{$7 / 10$} & 0.5 & $18.1 \pm 0.1$ & $24.4 \pm 0.1$ & $20.5 \pm 3.4$ \\
\hline & 3 & $19.1 \pm 0.5$ & $28.4 \pm 0.8$ & $7.2 \pm 0.8$ \\
\hline & 4 & $19.5 \pm 0.5$ & $30.3 \pm 0.3$ & $4.7 \pm 0.8$ \\
\hline \multirow{3}{*}{$7 / 30$} & 0.5 & $17.5 \pm 0.1$ & $25.5 \pm 0.2$ & $28.2 \pm 1.1$ \\
\hline & 3 & $19.2 \pm 0.1$ & $31.1 \pm 0.4$ & $4.1 \pm 2.2$ \\
\hline & 4 & $19.5 \pm 0.3$ & $31.1 \pm 0.1$ & $2.5 \pm 1.2$ \\
\hline \multirow{3}{*}{$8 / 14$} & 0.5 & $17.1 \pm 0.3$ & $27.1 \pm 0.2$ & $36.7 \pm 10.1$ \\
\hline & 3.5 & $17.1 \pm 0.6$ & $28.3 \pm 0.3$ & $6.7 \pm 1.7$ \\
\hline & 4.5 & $18.1 \pm 0.9$ & $30.1 \pm 0.6$ & $4.3 \pm 0.1$ \\
\hline
\end{tabular}
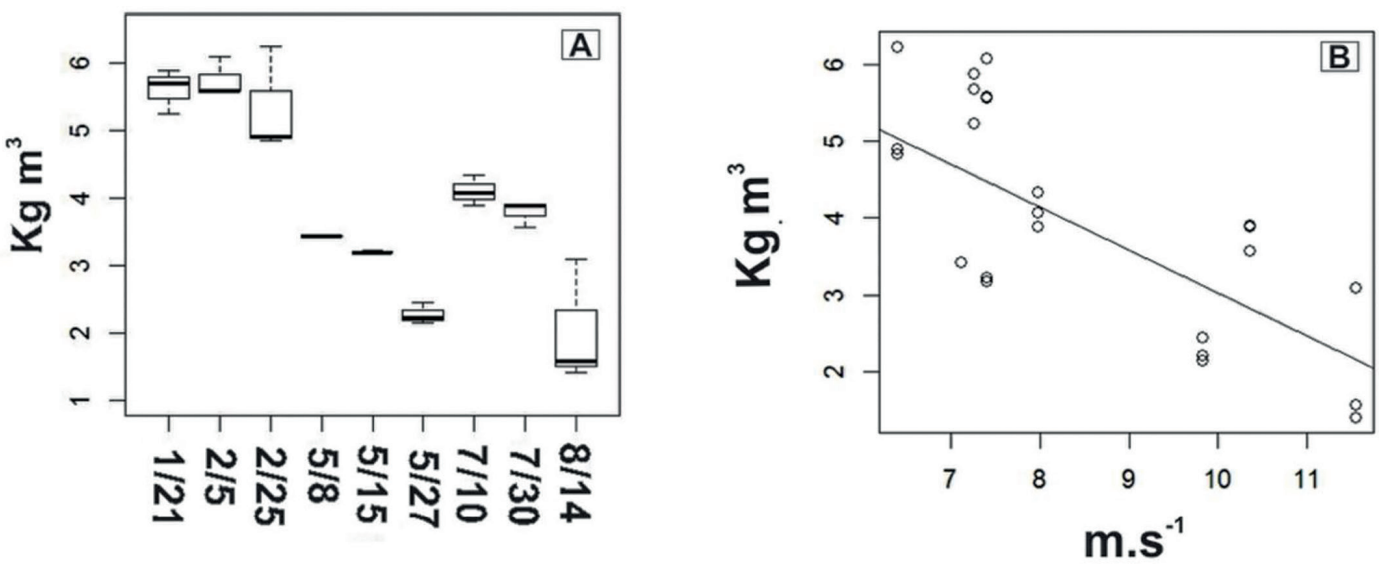

Figure 4. A- Median, quartiles, minimum and maximum values of stratification index in the summer $(1 / 21,2 / 5$ and $2 / 25)$, fall (5/8, $5 / 15$ and $5 / 27)$ and winter $(7 / 10,7 / 30$ and $8 / 14)$ sampling campaigns in the CCL. B- Correlation between stratification index and wind speed.

The mean concentrations of Chl-a were $8.4 \pm 5.4 \mu \mathrm{g} . \mathrm{L}^{-1}$ in summer, $6.2 \pm 2.3 \mu \mathrm{g} . \mathrm{L}^{-1}$ in fall, and 5.6 $\pm 4.7 \mu \mathrm{g} . \mathrm{L}^{-1}$ in winter. Maximum values were recorded in surface waters in January $\left(25.3 \mu \mathrm{g} . \mathrm{L}^{-1}\right)$ and August $\left(22.9 \mu \mathrm{g} . \mathrm{L}^{-1}\right)$, and the lowest value $\left(1.2 \pm 1.1 \mu \mathrm{g} . \mathrm{L}^{-1}\right)$ in the surface water in July. Pheophytin-a concentrations were similar in all seasons, with $3.4 \pm 2.7 \mu \mathrm{g} . \mathrm{L}^{-1}$ in summer, $2.9 \pm 2.8 \mu \mathrm{g} . \mathrm{L}^{-1}$ in fall and $3.2 \pm 2.6 \mu \mathrm{g} . \mathrm{L}^{-1}$ in winter (Table 2).

\section{StATiSTiCAL ANALYSES}

MDS showed both vertical and temporal separations (Figure 8). Surface waters were most associated with DO 

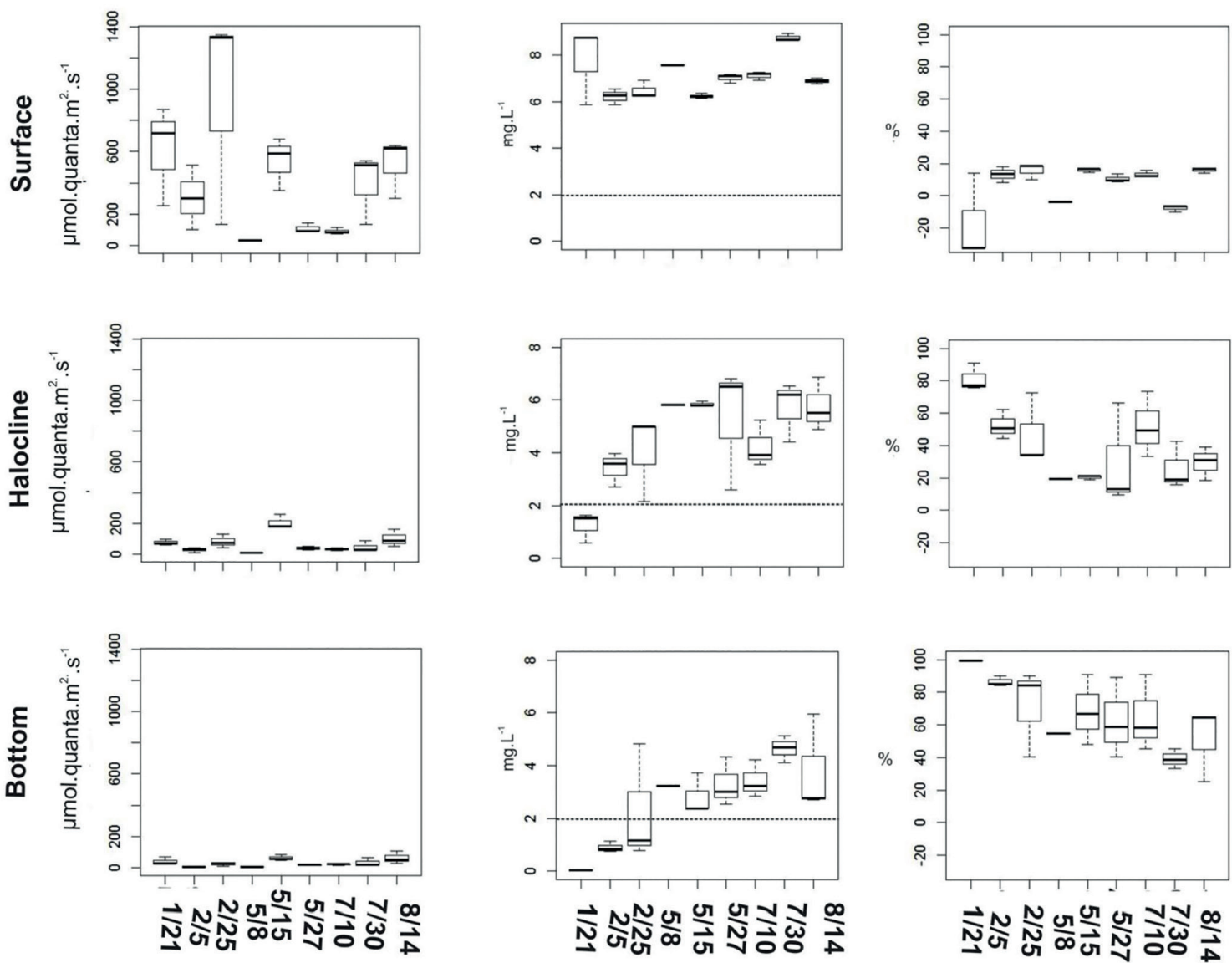

Figure 5. Median, quartiles, minimum and maximum of Photosynthetic Active Radiation ( $\mu$ mol.quanta. $\left.\mathrm{m}^{-2} \cdot \mathrm{s}^{-1}\right)$, Dissolved Oxygen (mg. $\left.\mathrm{L}^{-1}\right)$ and Apparent Oxygen Utilization (\%) in the surface, halocline and bottom waters of the CCL in summer (1/21, 2/5 and 2/25), fall (5/8,5/15 and 5/27) and winter $(7 / 10,7 / 30$ and $8 / 14)$ of 2014 . The line in DO graphs indicates the limit from oxic to hypoxic waters.

and PAR, while the bottom waters were most associated with salinity, DIP and Feo-a. Seasonal separation was caused by temperature, PAR and Chl-a, higher in summer, and by ammonium, nitrate and phosphate that were higher in winter (Figure 8). PERMANOVA corroborated with MDS, where vertical and temporal significant differences were observed in DO, PAR, salinity, temperature and phytoplankton pigment concentrations $(\mathrm{p}<0.01, \mathrm{n}=81)$.

\section{DISCUSSION}

The retention of coastal waters in the bottom of the CCL is caused by its geomorphology and vertical stratification, also the stability of the water column has been associated with wind patterns, since tides are usually cited as of minor importance to the lagoon water column mixing (KNOPPERS et al., 1984; ODEBRECHT;
CARUSO, 1987; SOUZA SIERRA et al., 1987). The lowest stratification indexes were observed in the colder days of fall and winter, which indicates a possible breakdown of water column stratification due the strong frequent southerly winds. However, as bottom waters salinity remained high compared to surface waters, wind shear turbulence was not strong enough to mix the entire water column.

In a stratified lagoon in Australia (Wamberal Lagoon), under similar depth ( \pm 5 meters $)$ and saline stratification, complete vertical water mixing was reported in winter when wind speed of $7.5 \mathrm{~m} . \mathrm{s}^{-1}$ persisted in association with tidal forces (GALE et al., 2006). Thus, the higher turbulence of the water column in the CCL caused by winds only, in fall and winter seasons, was not strong enough to promote a complete vertical mixing, as observed in Wamberal Lagoon. The water column is expected to return to a 
DIP
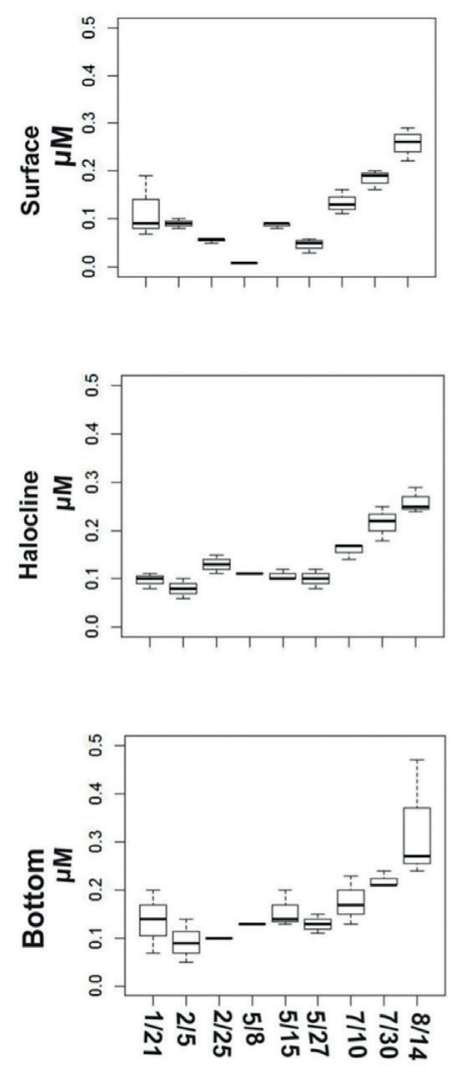

DIN
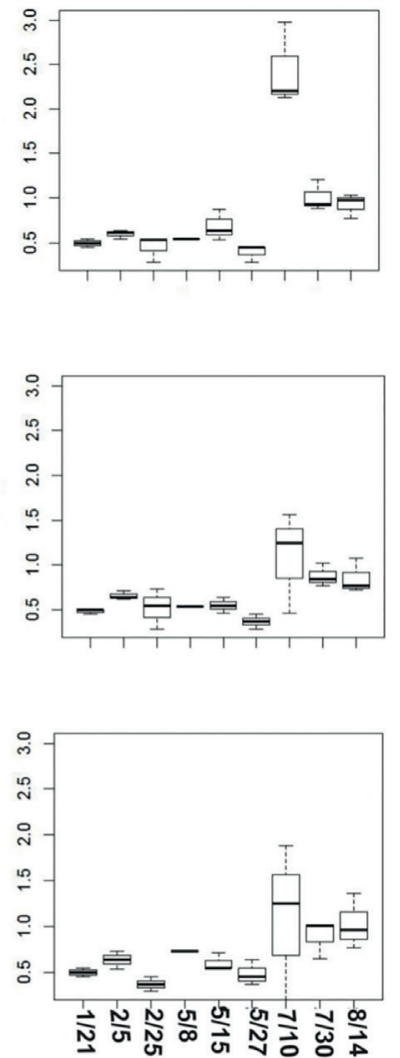

Figure 6. Median, quartiles, minimum and maximum of DIP $(\mu \mathrm{M})$ and DIN $(\mu \mathrm{M})$ in the surface, halocline and bottom waters of the CCL in summer $(21 / 1,5 / 2$ and $25 / 2)$, fall $(8 / 5$, $15 / 5$ and $27 / 5)$ and winter (7/10, 7/30 and 8/14) of 2014.

stable state very quickly due to the strong vertical density gradient, which could explain why the full homogenization of the water column was not observed. The total watershed area of the CL, that is made of basaltic steep slopes with small sub-watersheds, allows runoff with high water flow velocity (GODOY, 2008). This geological structure allows the high speed-runoffs to flow into the lagoon, promoting a turbulent mixing.

The water balance in coastal ecosystems is associated with freshwater inputs/losses and exchanges with adjacent marine systems (MCGLATHERY et al., 2001; KENNISH; PAERL, 2010). The temporal variability of water temperature and salinity offshore the Santa Catarina (SC) coast is influenced by different ocean water masses. In the summer, the Tropical Water (TW) and the South Atlantic Central Water (SACW) are the main water masses in the Santa Catarina shallow shelf (PIOLA et al., 2000; MÖLLER et al., 2008). In the winter, the intrusion of the
Plata River Plume Water (PPW) and Subtropical Coastal Water (SCW) predominate in the region, driven by the strength and frequency of southerly winds (PIOLA et al., 2000; MÖLLER et al., 2008; PIOLA et al., 2008). In this study, temperatures of $16^{\circ} \mathrm{C}$ and salinities of 32 in the CCL bottom waters were observed in summer $(2 / 25 / 2014)$, which could be associated with the intrusion of Coastal Waters (CW) under influence of SACW. In the winter, the bottom waters presented temperatures between 17.1 and $20.2^{\circ} \mathrm{C}$ and salinities between 29.6 and 31.3, which can indicate an intrusion of the CW under influence of the PPW. However, these hypotheses must be further tested using water mass isotopic tracers.

Strong pycnoclines between two water masses and high degradation of organic matter result in low diffusion rates of dissolved oxygen, causing its depletion in the deep waters (DIAZ, 2001; RABALAIS et al., 2009). In this study, hypoxic/anoxic conditions occurred in the bottom waters 
Table 2. Mean values ( \pm SD) of NP ratio, chlorophyll-a and pheophytin-a in the surface, halocline and bottom waters of the CCL in summer $(1 / 21,2 / 5$ and $2 / 25)$, fall $(5 / 8,5 / 15$ and $5 / 27)$ and winter $(7 / 10,7 / 30$ and $8 / 14)$ of 2014.

\begin{tabular}{|c|c|c|c|c|}
\hline Date & $\begin{array}{l}\text { Depth } \\
(\mathrm{m})\end{array}$ & NP & $\begin{array}{c}\text { Chlorophyll-a } \\
(\mu \mathrm{g} . \mathrm{L}-1)\end{array}$ & $\begin{array}{c}\text { Pheophytin-a } \\
\left(\mu \mathrm{g} . \mathrm{L}^{-1}\right)\end{array}$ \\
\hline \multirow{3}{*}{$21 / 01$} & 0.5 & $21 \pm 10$ & $15.4 \pm 8.4$ & $3.6 \pm 4.0$ \\
\hline & 3 & $14 \pm 2$ & $12.0 \pm 4.1$ & $3.2 \pm 2.6$ \\
\hline & 4 & $16 \pm 10$ & $11.3 \pm 4.4$ & $4.3 \pm 2.2$ \\
\hline \multirow{3}{*}{$05 / 02$} & 0.5 & $17 \pm 4$ & $6.2 \pm 4.6$ & $2.5 \pm 2.3$ \\
\hline & 3.5 & $26 \pm 12$ & $8.1 \pm 3.9$ & $4.4 \pm 3.3$ \\
\hline & 4.5 & $23 \pm 3$ & $5.3 \pm 2.3$ & $2.0 \pm 1.8$ \\
\hline \multirow{3}{*}{$25 / 02$} & 0.5 & $32 \pm 13$ & $3.6 \pm 0.8$ & $2.0 \pm 1.5$ \\
\hline & 3.5 & $17 \pm 8$ & $7.7 \pm 2.5$ & $3.3 \pm 1.2$ \\
\hline & 4 & $30 \pm 7$ & $7.0 \pm 2.8$ & $5.5 \pm 1.1$ \\
\hline \multirow{3}{*}{$08 / 05$} & 0.5 & $140 \pm 0$ & $4.3 \pm 0.0$ & $1.2 \pm 0.0$ \\
\hline & 3 & $17 \pm 0$ & $8.0 \pm 0.0$ & $3.5 \pm 0.0$ \\
\hline & 4 & $50 \pm 0$ & $11.5 \pm 0.0$ & $6.5 \pm 0.0$ \\
\hline \multirow{3}{*}{$15 / 05$} & 0.5 & $15 \pm 4$ & $3.0 \pm 0.6$ & $1.0 \pm 0.3$ \\
\hline & 2.5 & $31 \pm 29$ & $5.2 \pm 2.0$ & $2.2 \pm 0.3$ \\
\hline & 4 & $46 \pm 9$ & $6.6 \pm 0.4$ & $6.4 \pm 5.6$ \\
\hline \multirow{3}{*}{$27 / 05$} & 0.5 & $40 \pm 24$ & $7.1 \pm 3.4$ & $1.9 \pm 1.5$ \\
\hline & 4 & $27 \pm 23$ & $5.8 \pm 2.3$ & $1.8 \pm 0.4$ \\
\hline & 5 & $20 \pm 9$ & $5.2 \pm 1.7$ & $1.8 \pm 0.5$ \\
\hline \multirow{3}{*}{$10 / 07$} & 0.5 & $72 \pm 25$ & $1.9 \pm 1.0$ & $2.0 \pm 0.6$ \\
\hline & 3 & $80 \pm 45$ & $2.5 \pm 0.5$ & $2.2 \pm 0.3$ \\
\hline & 4 & $61 \pm 12$ & $2.5 \pm 0.9$ & $1.5 \pm 0.3$ \\
\hline \multirow{3}{*}{$30 / 07$} & 0.5 & $49 \pm 25$ & $6.3 \pm 2.8$ & $2.8 \pm 1.1$ \\
\hline & 3 & $23 \pm 16$ & $8.0 \pm 2.6$ & $3.6 \pm 1.8$ \\
\hline & 4 & $45 \pm 12$ & $8.7 \pm 5.8$ & $2.9 \pm 1.3$ \\
\hline \multirow{3}{*}{$14 / 08$} & 0.5 & $8 \pm 2$ & $10.8 \pm 8.6$ & $6.8 \pm 5.5$ \\
\hline & 3.5 & $22 \pm 16$ & $4.3 \pm 1.1$ & $2.3 \pm 0.5$ \\
\hline & 4.5 & $16 \pm 13$ & $5.9 \pm 1.4$ & $4.5 \pm 3.2$ \\
\hline
\end{tabular}

during summer, expanding up to halocline waters (January 2014). This event happened during the occurrence of the highest air temperatures and stratification indexes, and the smallest incident light values in the bottom. A negative correlation $\left(\mathrm{p}<0.05, \mathrm{r}^{2}-0.6, \mathrm{n}=27\right)$ was found between stratification index and bottom waters DO. FONTES and ABREU (2009) found this same inverse correlation in July 2005 (winter). They also observed a positive correlation in January 2006 (summer) due to the presence of superoxic waters in the bottom of the CCL. ODEBRECHT (1988) also found DO supersaturation in the CCL bottom waters in summer. The author attributed these values to high incidence of solar radiation throughout the water column, which favored the biological production of oxygen. Despite the higher radiation in summer, the bottom waters received less solar radiation in this study ( 2 to $67 \mu$ mol.quanta.m ${ }^{2} \cdot \mathrm{s}^{-1}$ ), when compared to FONTES; ABREU (2009), who reported 244 to $374 \mu \mathrm{mol}$.quanta. $\mathrm{m}^{-2} \cdot \mathrm{s}^{-1}$.

The CL watershed has a densely urbanized area and the sewage treatment is still in the early stages of development. Sewage runoff enter the lagoon in natura, which increases the water turbidity and organic matter concentrations, especially at low precipitation levels and high water residence time (FONSECA; BRAGA, 2006). In addition, the largest tributary to the CL (Joao Gualberto River) was dredged in January 2014, flushing more sediments as suspended materials into the lagoon. This event was one of the causes for low light penetration in summer in the $\mathrm{CCL}$, initiating the anoxic/hypoxic events, and confirming the anthropogenic activity effects on turbidity and water quality of this system.

Aerobic respiration processes are primarily responsible for DO consumption in the water column, boosting the anoxic and hypoxic events (GUPTA et al., 2008; ARAUJO et al., 2013). The exceeding allochthonous organic matter from domestic sewage and continental runoff increases the rates of aerobic oxidation of OM in the CCL waters, and consequently remineralization, and hypoxia/anoxia in the bottom waters (FONSECA; BRAGA, 2006; FONTES; ABREU, 2009).

The main allochthonous nutrient inputs into the CCL are runoff and domestic sewage, and the autochthonous sources are from the remineralization of OM (FONSECA et al., 2002; FONTES et al., 2006). Primary production and geochemical adsorption in the sediment are the major sinks of nutrients in the $\mathrm{CL}$, due the high water residence time of the CL. Higher nutrient concentrations were observed in winter, when compared to summer and fall. FONSECA; BRAGA (2006) reported high rates of nutrient regeneration in winter and primary production in summer, which help to explain the pattern found in our study. Assimilation by bacteria is also considered (FONTES; ABREU 2009). The nutrient vertical distribution indicates that bottom waters act as retention sites of materials, that when decomposed, enhances the water column with nutrients (ODEBRECHT; CARUSO, 1987; FONTES et al., 2011). However, no significant differences were observed for nutrient concentrations with depth.

Although the CCL bottom waters were usually related as a mineralization site, nutrients are not just found at this depth. Dissolved nutrients tend to suffer diffusion due to concentration differences between the water masses in stratified systems (LIBES, 1992; LIBES, 2009), or they can 
AMMONIUM
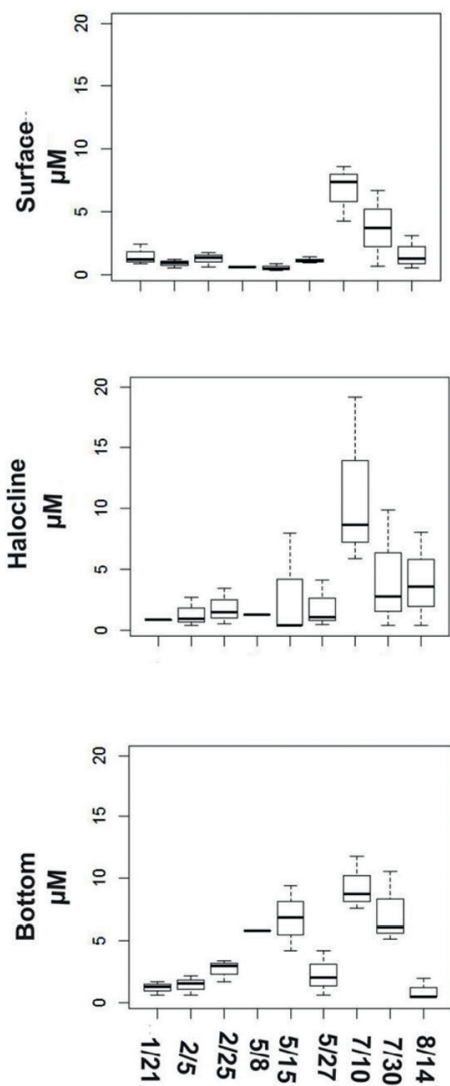

SILICATE
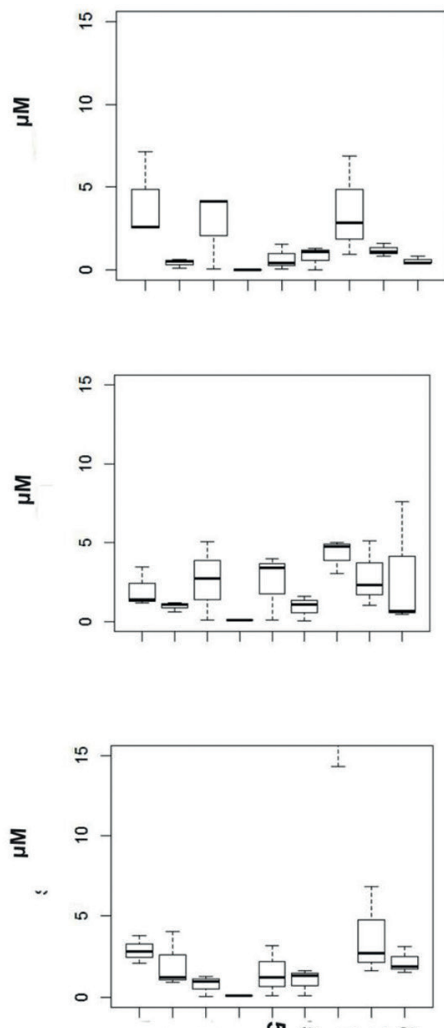

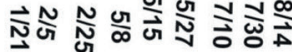

Figure 7. Median, quartiles, minimum and maximum of ammonium $(\mu \mathrm{M})$ and silicate $(\mu \mathrm{M})$ in the surface, halocline and bottom waters of the CCL in summer $(1 / 21,2 / 5$ and $2 / 25)$, fall $(8 / 5$, $15 / 5$ and $27 / 5)$ and winter (7/10, 7/30 and 8/14) of 2014.

Stress 0.17

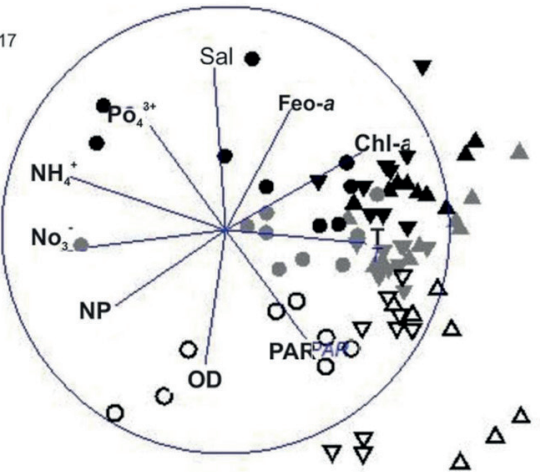

0

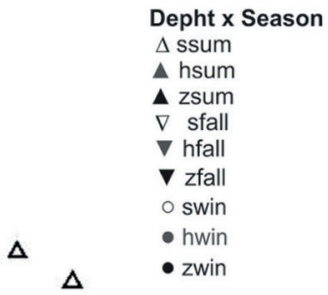

Figure 8. MDS plot of physical, chemical, and biological variables in the 3 depths: Surface (white), Halocline (gray) and Z bottom (black) waters in summer $(\boldsymbol{\Delta})$, fall ( $\boldsymbol{\nabla})$ and winter $(\bullet)$ in the CCL.

be assimilated by micro-organisms that predominate in these bottom suboxic-anoxic zones (FONTES; ABREU, 2009; 2012).
Nitrate is a strong oxidizer of organic matter in waters where oxygen is scarce, that result in the partial reduction of this element to ammonium or total reduction to 
atmospheric nitrogen via denitrification and ANAMMOX (NIXON, 1995; JØRGENSEN, 1996; DE JONGE et al., 2002). The main form of DIN in the CL has changed since the 2000's from nitrate to ammonium, a process associated with the increase of population density and an inadequate sewage treatment (FONSECA et al., 2002; FONTES et al., 2006). Ammonium has remained, since then, the dominant DIN form, especially when nutrient regeneration processes are more intense, as in winter (FONTES; ABREU, 2009). Despite of the potential reduction condition of the lagoon, either by ammonium high concentrations or hypoxic events, $\mathrm{N}$ remains in the dissolved inorganic form more easily than $\mathrm{P}$, reflecting the high NP ratio.

DIP dynamics in shallow waters are associated to its fast removal by geochemistry reactivity with organic matter and sediment particles via adsorption (DEBORDE et al., 2007). DIP desorption associated with clay minerals can occur in hypoxic/anoxic conditions, which increases $\mathrm{P}$ concentrations in the system, altering the NP ratio (BIANCHI, 2007). FONSECA (2006) found a peak of DIP in the CCL bottom waters during anoxic conditions, suggesting desorption of this nutrient from the sediment to the water column. However, the current study did not found DIP increase in anoxic bottom waters (summer), which suggests a regulation via biological assimilation in the warmer months, as observed by FONTES; ABREU $(2009,2012)$. The maximum DIP concentrations, as notice by the MDS analysis, were associated with bottom waters regardless of its oxidation state (i.e., even in the winter).

In conclusion, the dynamic of hypoxic and anoxic events in the CCL were associated with the physical stability of the water column due vertical variations in salinity, water exchange and mineralization of autochthonous and allochthonous organic materials. Nutrient patterns in the CCL were not clearly elucidated in this study, showing a gap of knowledge on microbial functional diversity, specially those involved in the nitrogen cycle. Continuous monitoring of the biogeochemical processes is necessary to better understand the lagoon dynamics.

\section{REFERENCES}

ARAUJO, M.; NORIEGA, C.; VELEDA, D.; LEFÈVRE, N. Nutrient input and $\mathrm{CO}_{2}$ flux of a tropical coastal fluvial system with high population density in the northeast region of Brazil. J. Water Resour. Protec., v. 5, n. 3A, p. 362-375, 2013.

ASSUMPÇÃO, D. T. G.; TOLEDO, A. P. P.; D’AQUINO, V. A. Levantamento ecológico da Lagoa da Conceição (Florianópolis, Santa Catarina) I: Caracterização-parâmetros ambientais. Ciênc. Cult., v. 33, n. 8, p. 1096-1101, 1981.
BENSON, B. B.; KRAUSE JR, D. The concentration and isotopic fractionation of oxygen dissolved in freshwater and seawater in equilibrium with the atmosphere. Limnol. Oceanogr., v. 29, n. 3, p. 620-632, 1984.

BIANCHI, T. S. Biogeochemistry of estuaries. New York: Oxford University Press, 2007. 706 p.

CLARKE, K. R.; WARWICK, R. M. Change in marine communities: an approach to statistical analysis and interpretation. $2^{\text {nd }}$ ed. Plymouth: Natural Environment Research Council, 1994. 144 p.

CLOERN, J. E. Our evolving conceptual model of the coastal eutrophication problem. Mar. Ecol. Prog. Ser., v. 210, p. $223-$ 253, 2001 .

CRUZ, O. A Ilha de Santa Catarina e o continente próximo; um estudo de geomorfologia costeira. Florianópolis: Editora UFSC, 1998. $276 \mathrm{p}$.

DEBORDE, J.; ANCHUTZ, P.; CHAILLOU, G.; ETCHEBER, H.; COMMARIEU, M. V.; LECROART, P.; ABRRIL, G. The dynamics of phosphorus in turbid estuarine systems: Example of the Gironde estuary (France). Limnol. Oceanogr. v. 52, n. 2 , p. $862-872,2007$

DE JONGE, V. N.; ELLIOT, M.; ORIVE, E. Causes, historical development, effects and future challenges of a common environmental problem: eutrophication. In: ORIVE, E.; ELLIOTT, M.; DE JONGE, V. N. (Eds.). Nutrients and Eutrophication in Estuaries and Coastal Waters. Dordrecht: Springer, 2002. p. 1-19.

DIAZ, R. J.; ROSENBERG, R. Spreading dead zones and consequences for marine ecosystems. Science, v. 321, n. 5891, p. 926-929, 2008.

DIAZ, R. J. Overview of hypoxia around the world. J. Environ. Qual., v. 30, p. 275-281, 2001

FONSECA, A.; BRAGA, E. S.; EICHLER, B. B. Distribuição Espacial dos Nutrientes Inorgânicos Dissolvidos e da Biomassa Fitoplanctônica no Sistema Pelágico da Lagoa da Conceição, Santa Catarina, Brasil (setembro, 2000). Atlântica, Rio Grande, v. 24, 2, p. 69-83, 2002.

FONSECA, A. Efeito da drenagem urbana nas características físicoquímicas e biológicas da água superficial na Lagoa da Conceição (Florianópolis, SC, Brasil). Biotemas, v. 19, n. 2, p. 7-16, 2006.

FONSECA, A.; BRAGA, E. S. Spatial and seasonal variation of dissolved inorganic nutrients and phytoplankton biomass in the pelagic system of the Conceição Lagoon, Southern Brazil. J. Coast. Res., si. 39, p. 1229-1233, 2006.

FONTES, M. L. S; CAVELLUCCI, R.; LAURENTI, A.; MACHADO, E. C.; CAMARGO, M. G.; BRANDINI, N. Detection of environmental impact on variations in dissolved nutrients and Chl-a in the Conceição Lagoon, Florianopolis, SC, Brazil. J. Coast. Res., si. 39, p. 1407-1412, 2006.

FONTES, M. L. S.; ABREU, P. C. Spatiotemporal Variation of Bacterial Assemblages in a Shallow Subtropical Coastal Lagoon in Southern Brazil. Microb. Ecol., v. 58, n. 1, p. 140-152, 2009.

FONTES, M. L. S.; SUZUKI, M. T.; COTTRELL, M. T.; ABREU, P. C. Primary production in a subtropical stratified coastal lagoon-contribution of anoxygenic phototrophic bacteria. Microb. Ecol., v. 61, n. 1, p. 223-237, 2011.

FONTES, M. L. S.; ABREU, P. C. A Vigorous specialized microbial food web in the suboxic waters of a shallow subtropical coastal lagoon. Microb. Ecol., v. 64, n. 2, p. 334-345, 2012.

GALE, E.; PATTIARATCHI, C.; RANASINGHE, R. Vertical mixing processes in intermittently closed and open lakes and lagoons, and the dissolved oxygen response. Estuar. Coast. Shelf Sci., v. 69, n. 1-2, p. 205-216, 2006. 
GODOY, F. B.; MÁRIO, H. F. S; FRANCO, D. O canal da Barra da Lagoa, Florianópolis - SC - um filtro de maré natural. Laboratório de Hidráulica Marítima - UFSC. In: Anais III - Seminário e workshop em Engenharia Oceânica. Rio Grande, 2008. 12 p.

GRASSHOFF, K.; EHRHARDT, M.; KREMLING, K. Methods of seawater analysis. $2^{\text {nd }}$ ed. Weinheim: Verlag Chemie, 1983. 419 p.

GREY, J. S.; Wu, R. S.; OR, Y. Y. Effects of hypoxia and organic enrichment on the coastal marine environment. Mar. Ecol. Prog. Ser., v. 238, p. 249-279, 2002.

GUPTA, G. V. M.; SARMA, V. V. S. S.; ROBIN, R. S.; RAMAN, A. V.; JAI KUMAR, M.; RAKESH, M.; SUBRAMANIAN, B. R. Influence of net ecosystem metabolism in transferring riverine organic carbon to atmospheric $\mathrm{CO}_{2}$ in a tropical coastal lagoon (Chilka Lake, India). Biogeochemistry, v. 87, n. 3, p. 265-285, 2008.

JØRGENSEN, B. Material flux in the sediment. In: JØRGENSEN, B.; RICHARDSON, K. (Eds.). Coastal and estuarine studies. Washington: American Geophysical Union, 1996. p. 115-135.

KENNISH, M. J.; PAERL, H. W. Coastal Lagoons Critical Habitats of Environmental Change. In: KENNISH, M. J.; PAERL, H. W. (Eds.). Coastal Lagoons: Critical Habitats of Environmental Change (Marine Science Series). Boca Raton: CRC Press, 2010. p. 1-16.

KNOPPERS, B. A.; OPITZ, S. S.; SOUZA, M. P.; MIGUEZ, C. F. The spatial distribution of particulate organic matter and some physical and chemical water properties in Conceição Lagoon; Santa Catarina, Brazil (July 19, 1982). Arq. Biol. Tecnol., v. 27, n. 1, p. 59-77, 1984.

LIBES, S. M. Introduction to marine biogeochemistry. $2^{\text {nd }}$ ed. San Diego: Academic Press, 2009. 928 p.

LIBES, S. M. An introduction to biogeochemistry. New York: John Wiley and Sons, $1992.734 \mathrm{p}$.

LLORET, J.; MARÍN, A.; MARÍN-GUIRAO, L. Is Coastal Lagoon Eutrophication Likely to be Aggravated by Global Climate Change? Estuar. Coast. Shelf Sci., v. 78, n. 2, p. 403-412, 2008.

LIU, M.; XIAO, T.; WU, Y.; ZHOU, F.; HUANG, H.; BAO, S.; ZHANG, W. Temporal distribution of bacterial community structure in the Changjiang estuary hypoxia area and adjacent east China sea. Environ. Res. Lett., v. 7, n. 2, p. 025001, 2012.

MCGLATHERY, K. J.; ANDERSON, I. C.; TYLER, A. C. Magnitude and variability of benthic and pelagic metabolism in a temperate coastal lagoon. Mar. Ecol. Prog. Ser., v. 216, p. $1-15,2001$

MÖLLER JR., O. O.; PIOLA, A. R.; FREITAS, A. C.; CAMPOS, E. J. D. The effects of river discharge and seasonal winds on the shelf off southeastern South America. Cont. Shelf Res., v. 28, n. 13, p. 1607-1624, 2008.

MUEHE, D.; CARUSO JR., F. Batimetria e algumas considerações sobre a evolução geológica da Lagoa da Conceição - Ilha de Santa Catarina. GEOSUL, Florianópolis, v. 4, n. 7, p. 32-44, 1989.

NOGUEIRA, E.; PÉREZ, F. F.; RÍOS, A. F. Seasonal patterns and long-term trends in an estuarine upwelling ecosystem (Ría de Vigo, NW Spain). Estuar. Coast. Shelf Sci., v. 44, n. 3, p. 285300, 1997.

NEWTON, A.; ICELY, J. D.; FALCÃO, M.; NOBRE, A., NUNES, J. P.; FERREIRA, J. G.; VALE, C. Evaluation of the eutrophication in the Ria Formosa coastal lagoon, Portugal. Cont. Shelf Res., v. 23, n. 17-19, p. 1945-1961, 2003.
NIXON, S. W. Coastal marine eutrophication: A definition, social causes, and future concerns. Ophelia, v. 41, n. 1, p. 199-219, 1995.

ODEBRECHT, C. Variações espaciais e sazonais do fitoplâncton, protozooplâncton e metazooplâncton na Lagoa da Conceição, Ilha de Santa Catarina, Brasil. Atlântica, v. 10, n. 1, p. 21-40, 1988

ODEBRECHT, C.; CARUSO JR, F. Hidrografia e matéria particulada em suspensão na Lagoa da Conceição, Ilha de Santa Catarina, SC, Brasil. Atlântica, v. 9, n. 1, p. 83-104, 1987.

PIOLA, A. R.; MÖLLER JR, O. O.; GUERRERO, R. A. CAMPOS, E. J. D. Variability of the subtropical shelf front of eastern South America: Winter 2003 and summer 2004. Cont. Shelf Res., v. 28, n. 13 , p. $1639-1648,2008$.

PIOLA, A. R.; CAMPOS, E. J. D.; MÖLLER JR, O. O.; CHARO, M.; MARTINEZ, C. Subtropical shelf front of eastern South America. J. Geophy Res., v. 105, n. C3, p. 6565-6578, 2000.

RABALAIS, N. N.; DÍAZ, R. J.; LEVIN, L.; TURNER, R. E.; GILBERT, D.; ZHANG, J. Dynamics and distribution of natural and human-caused hypoxia. Biogeosciences, v. 7, p. 585-619, 2010.

RABALAIS, N. N. Eutrophication. In: ROBINSON, A. R. (Ed.). The Sea, Volume 13: The Global Coastal Ocean: Multiscale Interdisciplinary Processes. Cambridge: Harvard University Press, 2004, p. 819-865.

RABALAIS, N. N.; TURNER, R. E. Hypoxia in the Northern Gulf of Mexico: Descriptions causes and change. In: RABALAIS, N. N.; TURNER, R. E. (Eds.). Coastal Hypoxia: Consequences for living resources and ecosystems. Washington: American Geophysical Union, 2001. p. 1-36.

RABALAIS, N. N.; TURNER, R. E.; DÍAZ, R. J.; JUSTIĆ, D. Global change and eutrophication of coastal waters. ICES J. Mar. Sci., v. 66, n. 7, p. 1528-1537, 2009.

RABALAIS, N. N.; TURNER, R. E.; WISEMAN Jr, W. J.; DORTCH, Q. Consequences of the 1993 Mississippi River flood in the Gulf of Mexico. River Res. Appl., v. 14, n. 2, p. 161-177, 1998.

SELMAN, M.; GREENHALGH, S.; DÍAZ, R.; SUGG, Z. Eutrophication and Hypoxia in Coastal Areas: A Global Assessment of the State of Knowledge. WRI Police Note. Water Qual. Eutrophication Hypoxia, v. 1, p. 1-6, 2008.

SIERRA DE LEDO, B.; SORIANO-SIERRA. Atributos e processos condicionantes da hidrodinâmica na Lagoa da Conceição, Ilha de Santa Catarina, Brasil. ACIESP, v. 2, p. 113-121, 1994.

SOUZA SIERRA, M. M.; SORIANO-SERRA, E. J.; SALIM, J. R. S. Distribuição espacial e temporal dos principais nutrientes e parâmetros hidrológicos da Lagoa da Conceição. An. Cient. UNALM, v. 2, p. 19-32, 1987.

STECKBAUER, A.; DUARTE, C. M.; CARSTENSEN, J.; VAQUER-SUNYER, R.; CONLEY, D. J. Ecosystem impacts of hypoxia: thresholds of hypoxia and pathways to recovery. Environ. Res. Lett., v. 6, n. 2, p. 025003, 2011.

STRAMMA, L.; JOHNSON, G. C.; SPRINTALL, J.; MOHRHOLZ, V. Expanding oxygen-minimum zones in the tropical oceans. Science, v. 320, n. 5876, p. 655-658, 2008.

STRICKLAND, J. D. H.; PARSONS, T. R. A Pratical Handbook of Seawater Analysis. Ottawa: Fisheries Research Board of Canada, 1972. $172 \mathrm{p}$.

ZANCHETTIN, D.; TRAVERSE, P.; TOMASINO, M. Observations on future sea level changes in the Venice lagoon. Hydrobiologia, v. 577, p. 41-53, 2007. 